\title{
PENGARUH UPAH MINIMUM TINGKAT PENGANGGURAN TERBUKA DAN JUMLAH PENDUDUK TERHADAP KEMISKINAN DI PROVINSI JAWA TENGAH
}

\author{
Yulia Adella Sari \\ Program Studi Ekonomi Pembangunan, Fakultas Ekonomi dan Bisnis, \\ UPN "Veteran" Jawa Timur, Surabaya, Indonesia \\ yuliasaridella@gmail.com
}

\begin{abstract}
Abstrak
Indonesia merupakan Negara berkembang, kemiskinan merupakan salah satu persoalan yang menjadi pusat perhatian pemerintah di negara manapun terutama di Indonesia, sehingga menjadi suatu fokus yang sangat penting untuk ditinjau melalui sebuah penelitian. Penelitian yang dilakukan, bertujuan untuk mengetahui pengaruh upah minimum, tingkat pengangguran terbuka, dan jumlah penduduk terhadap kemiskinan pada tahun 2010 hingga 2019 di Provinsi Jawa Tengah. Faktor pengaruh tersebut akan dibahas berlandaskan pada tinjauan pengertian kemiskinan, yang meliputi penyebab, ukuran dan indikator kemiskinan. Kemudian akan diukur berlandaskan tingkat pengangguran, yang memperhitungkan adanya jenis pengangguran, dampak pengangguran, upah minimum dan jumlah kependudukan. Adapun data sekunder yang digunakan dalam penelitian ini, diperoleh dari Badan Pusat Statistik Jawa Tengah dengan data berkala (time series). Sedangkan metode yang digunakan, mengacu pada metode kuantitatif, melalui analisis linier berganda dengan model Ordinary Least Square (OLS) dengan menggunakan SPSS 25.0 for windows. Melalui tahapan penelitian tersebut, menghasilkan jawaban bahwa upah minimum berpengaruh negative signifikan terhadap kemiskinan di provinsi Jawa Tengah, dan tingkat pengangguran terbuka berpengaruh positif signifikan terhadap kemiskinan di provinsi Jawa Tengah, serta jumlah penduduk berpengaruh positif signifikan terhadap kemiskinan di Jawa Tengah.
\end{abstract}

Kata Kunci: Kemiskinan, upah minimum, tingkat pengangguran terbuka, jumlah penduduk

\begin{abstract}
Poverty is one of the problems that has become the center of attention of the government in any country, especially in developing countries like Indonesia, so it is a very important focus to be reviewed through a study. The research conducted, aims to determine the effect of minimum influence, concern, and population on poverty in 2010 to 2019 in Central Java Province. These factors will be discussed based on an understanding of the definition, which includes causes, measures and indicators of poverty. Then it will be known the unemployment rate based on unemployment, which takes into account the type of unemployment, the impact of unemployment, the minimum wage and the total population. The secondary data used in this study was obtained from the Central Java Statistics Agency with periodic data (time series). While the method used refers to quantitative methods, through multiple linear analysis with the Ordinary Least Square (OLS) model using SPSS 25.0 for windows. Through these stages, it produces an answer that the minimum wage has a significant negative effect on poverty in Central Java province, and the open unemployment rate has a significant positive effect on poverty in Central Java province, and the population has a significant positive effect on poverty in Central Java.
\end{abstract}

Keywords: Poverty, minimum wage, open unemployment rate, population 


\section{PENDAHULUAN}

Kemiskinan merupakan persoalan individu masyarakat yang sulit untuk memenuhi kebutuhan hidup sehari-hari dikarenakan rendahnya kualitas sumberdaya yang dimiliki, Upah minimum yang tidak sesuai biaya hidup, serta meningkatnya jumlah penduduk mempengaruhi daya saing dalam berbagai sektor kebutuhan, terutama untuk mendapatkan pekerjaan. Persoalan tersebut, sejalan dengan penyebab kemiskinan menurut Suparlan (2004:31), yaitu kurangnya pendapatan dan aset (lack of income and assets) untuk memenuhi kebutuhan dasar seperti makanan, pakaian, perumahan dan tingkat kesehatan dan pendidikan yang diterima (acceptable). Sedangkan menurut BPS (2010:13) kemiskinan disebabkan menurut jenisnya, yaitu kemiskinan struktural dan kemiskinan kultural. Kemiskinan struktural adalah kemiskinan yang disebabkan karena struktur yang membuat sebagian kelompok masyarakat tertentu mendominasi sarana tentang ekonomi, social, politik, dan juga budaya. Kemiskinan kultural terindikasi dalam perilaku hidup boros, tingkat tabungan rendah, serta adanya sikap menerima atau pasrah terhadap lingkungan kemiskinan.

Mengatasi masalah kemiskinan tidak dapat dilakukan secara terpisah dari masalah-masalah yang telah dijelaskan tersebut, pendekatannya harus dilakukan lintas sektor, lintas pelaku secara terpadu dan terkoordinasi dan terintegrasi. Mengatasi masalah kemiskinan adalah usaha untuk menunjang perubahan dan kemajuan ekonomi serta memberikan kesempatan lebih besar untuk memecahkan berbagai masalah sosial. Mengatasi kemiskinan harus dilakukan secara terpadu sesuai prioritas dan kebutuhan masing-masing daerah dengan sasaran pembangunan nasional yang telah ditetapkan melalui pembangunan jangka panjang dan jangka pendek. Maka, salah satu indikator utama keberhasilan pembangunan nasional adalah laju penurunan jumlah penduduk miskin. Efektivitas dalam menurunkan jumlah penduduk miskin merupakan pertumbuhan utama dalam memilih strategi atau instrumen pembangunan suatu daerah, termasuk upaya mengatasi penurunan jumlah penduduk miskin di Provinsi Jawa Tengah. Karena permasalahan kemiskinan di Provinsi Jawa Tengah masih tergolong angka kemiskinan tinggi, jika dibandingkan dengan provinsi lain di pulau jawa.

Usaha pemerintah dalam penanggulangan masalah kemiskinan sangatlah serius, bahkan merupakan salah satu program prioritas, termasuk bagi pemerintah Provinsi Jawa Tengah. Menurut Bappeda Jawa Tengah (2007:16), upaya penanggulangan kemiskinan di Jawa Tengah dilaksanakan melalui lima pilar yang disebut Grand Strategy. Pertama, perluasan kesempatan kerja, ditujukan untuk menciptakan kondisi dan lingkungan ekonomi, politik, dan sosial yang memungkinkan masyarakat miskin memperoleh kesempatan dalam pemenuhan hak-hak dasar dan peningkatan taraf hidup secara berkelanjutan. Kedua, pemberdayaan masyarakat, untuk mempercepat kelembagaan sosial, politik, ekonomi, dan budaya masyarakat dan memperluas partisipasi masyarakat miskin dalam pengambilan keputusan kebijakan publik yang menjamin kehormatan, perlindungan, dan pemenuhan hak-hak dasar. Ketiga, peningkatan kapasitas, dilakukan untuk pengembangan kemampuan dasar, kemampuan masyarakat miskin agar dapat memanfaatkan perkembangan lingkungan. Keempat, perlindungan sosial untuk memberikan rasa aman bagi kelompok rentan dan masyarakat miskin baik laki-laki maupun perempuan yang disebabkan oleh bencana alam, krisis ekonomi, dan konflik sosial. Kelima, kemitraan regional, dilakukan untuk pengembangan dan menata ulang hubungan dan kerjasama lokal, regional, nasional, dan internasional guna mendukung pelaksanaan ke empat strategi diatas.

Penanggulangan kemiskinan di Jawa Tengah melalui Lima pilar tersebut, sesuai dengan landasan penyebab kemiskinan, yang dipengaruhi oleh beberapa faktor yaitu masalah upah, jumlah pengangguran dan pertumbuhan penduduk. Upah rendah yang diterima oleh masyarakat berpengaruh pada rendahnya pendapatan yang diterima masyarakat di suatu daerah sehingga pendapatan tersebut tidak bisa digunakan untuk memenuhi kebutuhan hidup sehari-hari. Upah yang rendah dapat disebabkan karena adanya perbedaan dalam kualitas sumber daya manusia. Kualitas sumber daya manusia yang rendah secara otomatis akan mempengaruhi tingkat produktivitas masyarakat. Kualitas sumber daya manusia sering dikaitkan oleh ketrampilan tinggi yang dimiliki oleh masyarakat. Adanya pelatihan serta pendidikan merupakan salah satu faktor penting dalam meningkatkan kualitas sumber daya manusia yang nantinya kualitas sumber daya manusia dapat mempengaruhi penentuan besar pendapatan yang diterima masyarakat, apabila faktor ini tidak diperhatikan oleh pemerintah, maka masyarakat miskin akan terjebak dalam lingkaran kemiskinan secara turun temurun (Sumarsono, 2003:11). Adanya ketentuan kenaikan nilai upah minimum, jumlahnya tetap harus menyesuaikan dengan kebutuhan hidup layak masyarakat, artinya bahwa adanya kenaikan upah tidak akan berarti jika angka Kebutuhan Hidup Layak (KHL) masih berkisar di atas julah upah minimum. 
Tingkat peRtumbuhan angkatan kerja yang cepat dan pertumbuhan lapangan kerja yang relatif lambat menyebabkan masalah pengangguran yang ada di suatu daerah menjadi semakin serius. Besarnya tingkat pengangguran merupakan cerminan kurang berhasilnya pembangunan di suatu negara. Pengangguran dapat mempengaruhi kemiskinan dengan berbagai cara (Tambunan, 2001:11). Pengangguran memiiliki huubungan yang sangat erat dalam mempengaruhi tingkat kemiskinan, standar hidup yang rendah dimanifestasikan secara kualitatif dan kuantitatif dalam bentuuk tingkat pendapatan sangat rendah, perumahan yang kurang layak, kesehatan yang buruk, bekal pendidikan yang minim, atau bahkan tidak ada sama sekali, angka kematian bayi yang tinggi, usia harapan hidup yang relatif sangat singkat dan peluang mendapatkan kerja yang rendah.

Faktor lain yang mempengaruhi kemiskinan adalah pertumbuhan penduduk yang tinggi. Pertumbuhan penduduk yang tinggi tanpa diimbangi dengan perbaikan kualitas penduduk serta peningkatan sumber daya pangan akan menjadikan kemiskinan semakin meningkat. Adanya jumlah penduduk yang tidak terkendali akan menghambat proses pembangunan ekonomi. Penduduk merupakan sejumlah manusia yang menempati suatu daerah tertentu pada waktu tertentu. Jumlah penduduk biasanya dikaitkan dengan pertumbuhan (income per capita) Negara tersebut, yang secara kasar mencerminkan kemajuan perekonomian Negara tersebut (Subri, 2003:2). Pertumbuhan penduduk yang tidak terkendali menurut Lincolin akan menimbulkan berbagai masalah dan hambatan bagi upaya-upaya yang dilakukan, karena pertumbuhan penduduk yang tinggi tersebut akan menyebabkan cepatnya pertambahan jumlah tenaga kerja, sedangkan kemampuan daerah dalam menciptakan kesempatan yang baru sangat terbatas (Arsyad,2004:10).

Berlandaskan pada tinjauan pengertian kemiskinan, meliputi penyebab, ukuran dan indikator kemiskinan. Serta memperhatikan tingkat pengangguran, yang memperhitungkan adanya jenis pengangguran, dampak pengangguran, upah minimum dan jumlah kependudukan. Maka, diperlukan penelitian lebih lanjut mengenai faktorfaktor tersebut, yang dapat mempengaruhi tingkat kemiskinan di Provinsi Jawa Tengah. Sehingga dapat digunakan sebagai rujukan dasar kebijakan bagi Provinsi Jawa Tengah baik di kabupaten atau kota. Maka penelitian ini, akan berfokus membahas persoalan: (1) pengaruh upah minimum terhadap kemiskinan di Provinsi Jawa Tengah, (2) pengaruh tingkat pengangguran terbuka terhadap kemiskinan di Provinsi Jawa Tengah, (3) pengaruh jumlah penduduk terhadap kemiskinan di Provinsi Jawa Tengah, dan (4) pengaruh upah minimum, tingkat pengangguran terbuka, dan jumlah penduduk secara bersama-bersama terhadap kemiskinan di Provinsi Jawa Tengah.

\section{TINJAUAN PUSTAKA}

Faktor pengaruh terhadap kemiskinan di Jawa Tengah dalam penelitian ini, akan dibahas berlandaskan pada tinjauan penyebab kemiskinan, yang menurut Kuncoro (2010:8) secara mikro, kemiskinan muncul karena adanya ketidaksamaan pola kepemikiran sumberdaya yang menimbulkan distribusi pendapatan yang timpang. Kemiskinian muncul akibat perbedaan dalam kualitas sumber daya manusia (SDM), kualitas SDM yang rendah berarti produktivitasnya rendah yang pada akhirnya akan mengakibatkan perolehan upah yang rendah juga. Keadaan rendahnya kualitas SDM ini diakibatkaan oleh rendahnya pendidikan di kalangan penduduk miskin elain itu ada faktor diskriminasi atau keturunan, dan kemiskinan muncul dikarenakan perbedaan akses dalam modal. Mengukur kemiskinan dibagi menjadi dua macam cara yaitu kemiskinan absolute dan kemiskinan relatif (Arsyad, 2004:7). Sedangkan menurut Badan Pusat Statistik (2010:12), terdapat beberapa indikator dalam mengukur kemiskinan antara lain: (1) Head Count Index (HCIP0) adalah presentase penduduk yang berada dibawah Garis Kemiskinan (GK). (2) Indeks kedalaman kemiskinan (Proverty Gap Index PI) yaitu merupakan ukuran rata-rata kesenjangan pengeluaran masing-masing penduduk miskin terhadap garis kemiskinan. Semakin tinggi nilai indeks, maka semakin jauh rata-rata pengeluaran penduduk dari garis kemiskinan. (3) Indeks Keparahan kemiskinan (Proverty Severity Index P2) yaitu adalah gambaran mengenai penyebaran pengeluaran di antara penduduk miskin. Semakin tinggi nilai indeks, maka akan semakin tinggi ketimpangan pengeluaran di antara penduduk miskin.

Adapun faktor pengaruh kemiskinan tersebut, akan diperhitungkan dengan adanya tingkat pengangguran, yang memperhitungkan adanya jenis pengangguran. Sumarsono (2003:10) menyatakan pengaangguran terjadi karena ketidak sesuaian antara permintaan dan penyedia dalam pasar kerja, sehingga memunculkan pengangguran Normal atau Friksional, musiman, siklikan, struktural dan teknologi. Kemiskinan akan mempengaruhi perekonomian suatu daerah dan bagi individu masyarakat menyebabkan kehilangan mata pencaharian dan pendapatan, kehilangan keterampilan dan timbulnya penyakit masyarakat (Feriyanto, 2014:5). Selain itu kemiskinan juga dipengaruhi oleh upah minimum, 
karena upah minimum yang tidak sesuai dengan meningkatnya nilai Kebutuhan Hidup Layak (KHL) di suatu daerah akan berdampak pada meningkatnya jumblah kemiskinan di daerah tersebut. Faktor-faktor tesebud minitik beratkan pada persoalan jumlah kependudukan, menurut Maier di kutip dari (Kuncoro, 1997:11), jumlah penduduk dalam pembangunan ekonomi suatu daerah merupakkan permasalahan mendasar. Karena pertumbuhan penduduk yang tidak terkendali dapat mengakibatkan tidak tercapainya tujuan pembangunan ekonomi.

\section{METODE PENELITIAN}

Jenis penelitian ini adalah penelitian kuantitatif. Penelitian kuantitatif menekankan pada pengujian teori-teori melalui pengukuran variabelvariabel penelitian dengan angka dan melakukan analisis data dengan prosedur statistik (Indriantoro \& Supomo, 2012:10). Variabel-variabel yang digunakan adalah variabel dependent yang menjadi variabel terikat (Y) adalah kemiskinan yang merupaakan suatu keadaan ketidak mampuan memenuhi standar minimum kebutuhan dasar yang meliputi kebutuhan makan maupun non makan. Kemudian Variabel independent adalah variabel yang mempengaruhi atau yang menjadi sebab perubahan pada variabel dependent (terikat). Meliputi upah minimum (X1), tingkat pengangguran terbuka (X2) dan Jumlah Penduduk (X3) (Sugiyono, 2014:4). Data sekunder pada penelitian ini berbentuk data time series. Data time series atau runtun waktu merupakan jenis data yang dikumpulkan menurut urutan waktu dalam suatu rentang waktu atau periode tertentu (Sugiyono. 2014:11). Data time series penelitian ini bersifat kuantitatif selama sepuluh tahun terakhir yaitu 2010 2019 dengan menggunakan data tahunan. Data yang digunakan dalam penelitian ini berasal dari web resmi BPS Jawa Tengah. Adapun langkah-langkah pengumpulan data dalam penelitian ini dilakukan dengan cara studi kepustakaan, dokumentasi dan riset Internet sebagai pengumpulan data dan informasi tambahan yang relevan dengan penelitian yang diteliti.

Teknik analisis data untuk mengetahui pengaruh dari variabel upah minimum, tingkat pengangguran terbuka, dan jumlah penduduk terhadap kesimkinan di Jawa Tengah dalam penelitian ini, menggunakan metode analisis Regresi Linier Berganda dengan menggunakan program computer software SPSS 25.0 for windows. Untuk mengetahui koefisien pada persamaan tersebut linier (tidak bias) dengan menggunakan asumsi BLUE (Best Linier Unbiased Estimate). Asumsi tersebut digunakan untuk mengetahui seberapa besar pengaruh dari variabel upah minimum, tingkat pengangguran terbuka, jumlah penduduk terhadap lesimkinan di Jawa Tengah. Pengujian asumsi tersebut yang digunakan dalam penelitian ini adalah uji autokorelasi, uji multikorelasi, dan uji heterokedastisitas (Ghozali, 2014:10). Dalam mengujiregresi tersebut harus terbebas dari uji BLUE agar pengambilan uji $\mathrm{F}$ dan Uji t menjadi tidak bias (Sugiyono, 2014:21).

\section{HASIL DAN PEMBAHASAN}

Penelitian dilakukan untuk menganalisis pengaruh upah minimum, tingkat pengangguran terbuka, dan jumlah penduduk terhadap kemiskinan di provinsi Jawa Tengah. Sumber data yang digunakan dalam penelitian ini berasal dari Badan Pusat Statistik Jawa Tengah dengan data time series atau runtun waktu merupakan jenis data yang dikumpulkan menurut urutan waktu dalam suatu rentang waktu atau periode tertentu. Data time series penelitian ini bersifat kuantitatif selama sepuluh tahun terakhir yaitu 2010 - 2019 dengan menggunakan data tahunan.

\section{Kemiskinan}

Kemiskinan merupakan persoalan kompleks yang terjadi di Negara Indonesia termasuk di Provinsi Jawa Tengah. Pemerintah Provinsi jawa Tengah sangat serius memperhatikan dalam penanggulangan masalah kemiskinan, bahkan merupakan salah satu program prioritas. Untuk melihat lebih jelasnya jumlah kemiskinan Provinsi Jawa Tengah, dapat dilihat pada Tabel berikut:

\begin{tabular}{|c|c|}
\hline Tahun & $\begin{array}{c}\text { Jumlah Kemiskinan } \\
\text { (Persen) }\end{array}$ \\
\hline $\mathbf{2 0 1 0}$ & $16 \%$ \\
\hline $\mathbf{2 0 1 1}$ & $16,21 \%$ \\
\hline $\mathbf{2 0 1 2}$ & $14,9 \%$ \\
\hline $\mathbf{2 0 1 3}$ & $14,4 \%$ \\
\hline $\mathbf{2 0 1 4}$ & $13,5 \%$ \\
\hline $\mathbf{2 0 1 5}$ & $13,5 \%$ \\
\hline $\mathbf{2 0 1 6}$ & $13,2 \%$ \\
\hline $\mathbf{2 0 1 7}$ & $13 \%$ \\
\hline $\mathbf{2 0 1 8}$ & $11 \%$ \\
\hline $\mathbf{2 0 1 9}$ & $10 \%$ \\
\hline
\end{tabular}

Tabel 1. Data Jumlah Kemiskinan Provinsi Jawa Tengah (Sumber: BPS Jawa Tengah (diolah))

Berdasarkan Tabel 1 berdasarkan Badan Pusat Statistik Jawa Tengah mencatat bahwa peningkatan 
tertinggi Tingkat Kemiskinan di Provinsi Jawa Tengah terjadi pada tahun 2011 yaitu sebesar 16,21\%. Kemudian ditahun 2012 sampai dengan 2019 cenderung mengalami penurunan mencapai $10 \%$ atau sekitar 34.718.204 penduduk miskin.

\section{Upah Minimum}

Data kemiskinan di Provinsi Jawa Tengah dari tahun 2010-2019, tidak lepas dari faktor pengaruh upah rendah yang diterima oleh masyarakat. Upah minimum akan berpengaruh pada rendahnya pendapatan yang diterima masyarakat suatu daerah sehingga pendapatan tersebut tidak bisa digunakan untuk memenuhi kebutuhan hidup sehari-hari. Upah yang rendah dapat disebabkan karena adanya perbedaan dalam kuAlitas sumber daya manusia di Provinsi Jawa Tengah. Berikut data tabel upah minimum di Provinsi Jawa Tengah dari tahun 20102019:

\begin{tabular}{|l|l|l|}
\hline Tahun & $\begin{array}{c}\text { Upah } \\
\text { Minimum } \\
\text { (Rupiah) }\end{array}$ & $\begin{array}{c}\text { Perkembangan } \\
\text { (Persen) }\end{array}$ \\
\hline $\mathbf{2 0 1 0}$ & $630.000,00$ & $0,26 \%$ \\
\hline $\mathbf{2 0 1 1}$ & $705.000,00$ & $0,12 \%$ \\
\hline $\mathbf{2 0 1 2}$ & $745.000,00$ & $0,6 \%$ \\
\hline $\mathbf{2 0 1 3}$ & $866.250,00$ & $0,16 \%$ \\
\hline $\mathbf{2 0 1 4}$ & $1.000 .000,00$ & $0,15 \%$ \\
\hline $\mathbf{2 0 1 5}$ & $1.000 .000,00$ & $0 \%$ \\
\hline $\mathbf{2 0 1 6}$ & $1.265 .000,00$ & $0,26 \%$ \\
\hline $\mathbf{2 0 1 7}$ & $1.367 .000,00$ & $0,8 \%$ \\
\hline $\mathbf{2 0 1 8}$ & $1.486 .065,00$ & $0,8 \%$ \\
\hline $\mathbf{2 0 1 9}$ & $1.605 .396,00$ & $0,8 \%$ \\
\hline
\end{tabular}

Tabel 2. Data Upah Minimum Provinsi Jawa Tengah (Sumber: BPS Jawa Tengah (diolah))

\section{Pengangguran}

Selain upah minimum, faktor yang mempengaruhi kemiskinan di Provinsi Jawa Tengah adalah tingkat pengangguran. Pengangguran diukur dengan keadaan di mana angkatan kerja yang ingin memperoleh pekerjaan, tapi belum mendapatkannya. Berikut data tabel tingkat pengangguran di Provinsi Jawa Tengah pada tahun 2010-2019 menurut BPS:

\begin{tabular}{|c|c|}
\hline Tahun & $\begin{array}{c}\text { Tingkat Pengangguran } \\
\text { (Persen) }\end{array}$ \\
\hline $\mathbf{2 0 1 0}$ & $6,21 \%$ \\
\hline $\mathbf{2 0 1 1}$ & $7,07 \%$ \\
\hline $\mathbf{2 0 1 2}$ & $5,61 \%$ \\
\hline $\mathbf{2 0 1 3}$ & $6,01 \%$ \\
\hline
\end{tabular}

\begin{tabular}{|l|l|}
\hline $\mathbf{2 0 1 4}$ & $5,68 \%$ \\
\hline $\mathbf{2 0 1 5}$ & $4,63 \%$ \\
\hline $\mathbf{2 0 1 6}$ & $4,99 \%$ \\
\hline $\mathbf{2 0 1 7}$ & $4,57 \%$ \\
\hline $\mathbf{2 0 1 8}$ & $4,51 \%$ \\
\hline $\mathbf{2 0 1 9}$ & $4,49 \%$ \\
\hline
\end{tabular}

Tebel 3. Data Tingkan Pengangguran di Provinsi Jawa Tengah (Sumber: BPS Jawa Tengah (diolah))

Pada Tingkat Pengangguran Terbuka di Provinsi Jawa Tengah cukup berfluktuatif, dimana pada tahun 2010 Tingkat Pengangguran Terbuka Provinsi Jawa Tengah sebesar $6,21 \%$ kemudian mengalami peningkatan di tahun 2011 sebesar 7,07\%, setelah itu menurun di tahun 2012 sebesar 5,61\%, dan meningkat kembali pada tahun 2013 sebesar 6,01\%, namun di tahun 2014 hingga tahun 2019 terus mengalami penurunan hingga $4,49 \%$.

\section{Jumlah Penduduk}

Faktor pengaruh kemiskinan tidak lepas dari persoalan pertumbuhan jumlah penduduk di Provinsi Jawa Tengah. Karena pertumbuhan penduduk yang tinggi tanpa diimbangi dengan perbaikan kualitas penduduk serta peningkatan sumber daya pangan akan menjadikan kemiskinan semakin meningkat. Adanya jumlah penduduk yang tidak terkendali akan menghambat proses pembangunan ekonomi. Perkembangan jumlah penduduk Provinsi Jawa Tengah secara umum mengalami fluktuasi dan kenaikan di tiap-tiap wilayah dalam jangka waktu sepuluh tahun terakhir, sebagaimana data tabel berikut:

\begin{tabular}{|l|l|l|}
\hline Tahun & $\begin{array}{c}\text { Jumlah } \\
\text { Penduduk }\end{array}$ & $\begin{array}{c}\text { Perkembangan } \\
\text { (Persen) }\end{array}$ \\
\hline $\mathbf{2 0 1 0}$ & 32.443 .886 & $0,6 \%$ \\
\hline $\mathbf{2 0 1 1}$ & 32.725 .378 & $0,8 \%$ \\
\hline $\mathbf{2 0 1 2}$ & 32.998 .692 & $0,8 \%$ \\
\hline $\mathbf{2 0 1 3}$ & 33.264 .339 & $0,7 \%$ \\
\hline $\mathbf{2 0 1 4}$ & 33.522 .663 & $0,8 \%$ \\
\hline $\mathbf{2 0 1 5}$ & 33.774 .141 & $0,8 \%$ \\
\hline $\mathbf{2 0 1 6}$ & 34.019 .095 & $0,7 \%$ \\
\hline $\mathbf{2 0 1 7}$ & 34.257 .865 & $0,8 \%$ \\
\hline $\mathbf{2 0 1 8}$ & 34.490 .835 & $0,8 \%$ \\
\hline $\mathbf{2 0 1 9}$ & 34.718 .204 & $0,8 \%$ \\
\hline
\end{tabular}

Tabel 4. Data Jumlah pertumbuhan Penduduk Provinsi Jawa Tengah (Sumber: Badan Pusat Statistik (data diolah)) 


\section{Hasil Pengujian}

\section{Uji Asumsi Klasik}

Pengujian ini dilakukan untuk memperoleh hasil estimasi yang BLUE (Best Linier Unbiased Estimator) atau perkiraan linier tidak bias yang terbaik maka estimasi tersebut harus memenuhi beberapa asumsi yang berkaitan. Apabila salah satu asumsi tersebut dilanggar, maka persamaan regresi tidak lagi bersifat BLUE. Sehingga pengambilan keputusan melalui Uji $\mathrm{F}$ dan Uji t menjadi bias. Dalam hal ini harus dihindarkan terjadinya kasuskasus sebagai berikut:

\section{Autokorelasi}

Autokorelasi adalah korelasi antara data observasi yang diurutkan berdasarkan kurun waktu (time series) atau data yang diambil pada waktu tertentu (cross section). autokorelasi digunakan untuk menguji variabel-variabel yang diteliti apakah terjadi autokorelasi atau tidak dapat menggunakan uji Durbin-Watson, yaitu dengan cara membandingkan nilai Durbin-Watson yang dihitung dengan nilai Durbin-Watson (dL dan dU) dalam tabel. Kaidah keputusan dapat dijelaskan sebagai berikut:

1. Jika d lebih kecil dari pada $\mathrm{dL}$, atau lebih besar dari pada (4-dL), maka hipotesis nol $(\mathrm{H} 0)$ ditolak yang berarti yang berarti terdapat autokorelasi.

2. Jika d terletak antara dU dan (4-dU), maka hipotesis nol $(\mathrm{H} 0)$ diterima yang berarti tidak ada autokorelasi.

3. Jika nilai $\mathrm{d}$ terletak antara $\mathrm{dL}$ dan $\mathrm{dU}$ atau antara (4-dL) dan (4- dU), maka uji Durbin-Watson tidak menghasilkan kesimpulan yang pasti, untuk nilai-nilai ini tidak dapat disimpulkan ada tidaknya autokorelasi diantara faktor-faktor pengganggu.

\begin{tabular}{|c|c|c|c|c|c|}
\hline \multicolumn{5}{|c|}{ Change Statistics } & Durb \\
\cline { 1 - 5 } $\begin{array}{c}\text { R Square } \\
\text { Change }\end{array}$ & $\begin{array}{c}\text { F } \\
\text { Change }\end{array}$ & $\begin{array}{c}\text { Df } \\
1\end{array}$ & Df2 & $\begin{array}{c}\text { Sig. F } \\
\text { Chang } \\
\text { e }\end{array}$ & $\begin{array}{c}\text { in- } \\
\text { Wats } \\
\text { on }\end{array}$ \\
\hline 0,946 & 35,108 & 3 & 6 & 0,000 & 1,729 \\
\hline
\end{tabular}

Tabel 5. Uji Autokorelasi Model Summary

Dari hasil analisis untuk uji autokorelasi pada penelitian ini diperoleh nilai $D W$ test sebesar 1,893. Untuk mengetahui ada tidaknya gejala autokorelasi dalam model penelitian maka dapat dibuktikan dengan kurva $D W$. Dalam persamaan ini jumlah variabel bebas (k) adalah 3 dan banyaknya data (n) adalah 10 sehingga diperoleh nilai $D W$ tabel adalah sebesar $\mathrm{dL}=0,5253$ dan $\mathrm{dU}=2,0163$. Berdasarkan hasil analisis, maka dalam model regresi ini tidak terjadi gejala autokorelasi karena nilai $\mathrm{DW}_{\text {test }}$ yang diperoleh adalah sebesar 1,729 yang berada pada daerah antara $\mathrm{dL}$ dan $\mathrm{dU}$ yang berarti berada dalam daerah keragu- raguan atau ketidakpastian. Sehingga dapat digunakan untuk melakukan pengujian selanjutnya.

\section{Multikolinearitas}

Multikolinearitas digunakan untuk menguji apakah dalam model regresi ditemukan ada atau tidaknya korelasi antar variabel bebas. Untuk mengetahui adanya gejala multikolinearitas dapat dilihat dari besarnya VIF. Apabila VIF kurang dari 10 maka regresi terbebas dari gejala multikolinearitas, sedangkan apabila VIF lebih besar dari 10 maka regresi tersebut terjadi multikolinearitas. Adapun hasil yang diperoleh setelah diadakan pengujian analisis regresi linier berganda diketahui bahwa dari ketiga variabel bebas yang dianalisis dapat dilihat pada tabel berikut :

\begin{tabular}{|c|c|c|c|}
\hline Variabel & VIF & Ketentuan & Keterangan \\
\hline $\mathrm{X} 1$ & 4,378 & $\leq 10$ & $\begin{array}{c}\text { Tidak Terjadi } \\
\text { Multikolinier }\end{array}$ \\
\hline $\mathrm{X} 2$ & 5,674 & $\leq 10$ & $\begin{array}{c}\text { Tidak Terjadi } \\
\text { Multikolinier }\end{array}$ \\
\hline $\mathrm{X} 3$ & 5,542 & $\leq 10$ & $\begin{array}{c}\text { Tidak Terjadi } \\
\text { Multikolinier }\end{array}$ \\
\hline
\end{tabular}

Tabel 6. Uji Multikolinearitas

Maka hasil yang diperoleh setelah diadakan pengujian analisis regresi linier berganda diketahui bahwa dari ketiga variabel bebas dengan VIF untuk $\mathrm{X} 1$ sebesar 4,378; VIF untuk X2 sebesar 5,678; VIF untuk X3 sebesar 5,542 yang berarti dari kedua variabel bebas lebih kecil dari 10 sehingga dalam model regresi ini tidak terjadi multikolinearitas.

\section{Heterokedastisitas}

Heterokedastisitas digunakan untuk menguji apakah dalam model regresi terjadi ketidaksamaan varian dari residual satu pengamatan ke pengamatan yang lain. Hal ini bisa diidentifikasikan dengan menghitung korelasi Rank Spearman antara residual dengan seluruh variabel bebas. Pembuktian ada atau tidaknya heterokedastisitas dilihat pada tabel dibawah ini: 


\begin{tabular}{|c|c|c|c|c|c|}
\hline Variabel & $\begin{array}{c}\text { Tailed } \\
\mathbf{( X 1 )}\end{array}$ & $\begin{array}{c}\text { Tailed } \\
\mathbf{( X 2 )}\end{array}$ & $\begin{array}{c}\text { Tailed } \\
\mathbf{( X 3 )}\end{array}$ & $\begin{array}{c}\text { Ketent } \\
\text { uan }\end{array}$ & $\begin{array}{c}\text { Keterang } \\
\mathbf{a n}\end{array}$ \\
\hline Kemiskinan & 0,751 & 0,803 & 0,829 & $\geq 0,05$ & $\begin{array}{c}\text { Tidak } \\
\text { terjadi } \\
\text { heteroked } \\
\text { astisitas }\end{array}$ \\
\hline
\end{tabular}

Tabel 7. Tes Heterokedastisitas dengan Korelasi Rank Spearman

Berdasarkan tabel diatas, diperoleh tingkat signifikan koefisien korelasi Rank Spearman untuk variabel bebas X1 sebesar 0,751; X2 sebesar 0,803; $\mathrm{X} 2$ sebesar 0,829 terhadap residual lebih besar dari 0,05 (tidak signifikan), sehingga tidak mempunyai korelasi yang berarti antara nilai residual dengan variabel yang menjelaskan. Jadi dapat disimpulkan persamaan tersebut tidak terjadi heterokedastisitas. Berdasarkan hasil dari Uji Asumsi Klasik yang telah dilakukan diatas dapat disimpulkan bahwa pada model penelitian ini tidak terjadi pelanggaran asumsi klasik, maka dapat dilakukan analisis selanjutnya.

\section{Analisis Regresi Linear Berganda}

Dalam penelitian ini digunakan analisis regresi linier berganda dan untuk mengolah data yang ada digunakan alat bantu komputer dengan program SPSS (Statistic Program For Social Science) versi 25. Berdasarkan hasil analisis diperoleh persamaan regresi linier berganda sebagai berikut:

$$
\begin{aligned}
& \mathrm{Y}=78,854-0,00008 \mathrm{X}_{1}+0,014 \mathrm{X}_{2}- \\
& 0,0019 \mathrm{X} 3
\end{aligned}
$$

Berdasarkan persamaan tersebut diatas, maka dapat dijelaskan melalui penjelasan sebagai berikut:

$\beta 0=$ Nilai konstanta sebesar 78,854 menunjukkan apabila Upah Minimum (X1), Tingkat Pengangguran (X2), dan Jumlah Penduduk (X3) konstan maka Tingkat kemiskinan (Y) akan naik sebesar 78,854 jiwa.

$\beta 1=-0,00008$ menunjukkan setiap Upah Minimum (X1) naik seratus ribu, maka Tingkat kemiskinan (Y) akan turun sebesar 0,00008\% apabila Tingkat Pengangguran (X2), dan Jumlah Penduduk (X3) konstan.

$\beta 2=0,014$ menunjukkan setiap Tingkat Pengangguran (X2) naik satu persen, maka Tingkat kemiskinan (Y) akan naik sebesar 0,014 \% apabila Upah Minimum (X1), dan Jumlah Penduduk (X3).

B3 $=-0,0019$ menunjukkan setiap Jumlah Penduduk (X3) naik seratus ribu, maka Tingkat kemiskinan $(\mathrm{Y})$ akan turun sebesar
0,0019\% apabila Upah Minimum (X1), Tingkat Pengangguran (X2) konstan.

\section{Uji Koefisien Determinasi $\left(R^{2}\right)$}

Pengujian ini dilakukan untuk mengukur seberapa jauh kemampuan variabel- variabel bebas dalam menerangkan variabel terikat. Dari perhitungan dengan program SPSS diperoleh hasil perhitungan $\mathrm{R}^{2}$ ( $\mathrm{R}$ Square) sebesar 0,946 artinya 94,6\% dari seluruh pengamatan menunjukkan variabel bebas Upah Minimum (X1), Tingkat Pengangguran (X2), dan Jumlah Penduduk (X3) mampu menjelaskan variasi variabel terikatnya yaitu Tingkat kemiskinan (Y), sisanya 5,4\% adalah dijelaskan oleh faktor lain yang tidak tampak pada model.

\section{Uji F}

Uji hipotesis ini dilakukan untuk mengetahui adanya pengaruh atau hubungan secara simultan antara variabel bebas $\mathrm{X}$ terhadap variabel terikat $\mathrm{Y}$ digunakan uji $\mathrm{F}$ dari perhitungan dengan program SPSS diperoleh hasil perhitungan yang dapat dilihat

\begin{tabular}{|c|c|c|c|c|c|c|}
\hline \multicolumn{7}{|c|}{$A N O V A^{b}$} \\
\hline \multicolumn{2}{|l|}{ Model } & $\begin{array}{l}\text { Sum of } \\
\text { Squares }\end{array}$ & df & Mean Square & $\mathrm{F}$ & Sig. \\
\hline \multirow[t]{3}{*}{1} & Regression & 27,484 & 3 & 9,161 & 35,108 & $.000^{8}$ \\
\hline & Residual & 1,566 & 6 & 261 & & \\
\hline & Total & 29,049 & 9 & & & \\
\hline
\end{tabular}
dalam tabel sebagai berikut :

Tabel 9. Analisis Varian (ANOVA)

Berdasarkan tabel diatas untuk menguji pengaruh simultan digunakan uji $\mathrm{F}$ dengan langkahlangkah sebagai berikut:

a) $\mathrm{H}_{0}: \beta 1=\beta_{2}=\beta 3=0$

Secara simultan variabel bebas tidak ada pengaruh terhadap variabel terikat.

$\mathrm{Ha}_{\mathrm{a}}: \beta 1 \neq \beta 2 \neq \beta 3 \neq 0$

Secara simultan variabel bebas ada pengaruh terhadap variabel terikat.

b) $\alpha=0,05$ dengan df 1 (degree of freedom) $=$ $3 \mathrm{df} 2$ (degree of freedom $)=6$

c) $\mathrm{F}$ tabel $(\alpha=0,05)=4,76$

d) F hitung $=35,108$

e) Daerah pengujian. Karena $\mathrm{F}$ hitung = 35,108 > F tabel $=3$,16. maka H0 ditolak dan $\mathrm{H}_{\mathrm{a}}$ diterima. Yang artinya bahwa secara simultan variabel bebas yaitu Upah Minimum (X1), Tingkat Pengangguran (X2), dan Jumlah Penduduk (X3) berpengaruh positif dan signifikan secara simultan terhadap variabel terikatnya yaitu 
variabel tingkat kemiskinan.

Uji t

Uji hipotesis ini dilakukan untuk menguji pengaruh secara parsial dari variabel bebas Tingkat Pengangguran (X1), dan Tingkat Inflasi (X2) terhadap tingkat kemiskinan. Hasil uji hipotesis tersebut dapat dilihat dalam tabel sebagai berikut :

\begin{tabular}{|l|l|l|l|}
\hline Model & $t$ Hitung & Sig. & $t$ Tabel \\
\hline $\begin{array}{l}\text { X1 = Upah } \\
\text { Minimum }\end{array}$ & $\mathbf{- 3 , 9 1 6}$ & 0,006 & 2,446 \\
\hline $\begin{array}{l}\text { X2 = } \\
\begin{array}{l}\text { Tingkat } \\
\text { Pengangura } \\
\text { n }\end{array}\end{array}$ & 0,030 & 0,977 & 2,446 \\
\hline $\begin{array}{l}\text { X2 = } \\
\text { Jumlah } \\
\text { Penduduk }\end{array}$ & $-\mathbf{4 , 6 8 8}$ & 0,002 & 2,446 \\
\hline
\end{tabular}

Tabel 10. Hasil Uji Hipotesis secara Parsial dari Variabel

Berdasarkan tabel diatas untuk menguji pengaruh masing- masing variabel terhadap variabel terikatnya, dapat dianalisa melalui uji $t$ dengan langkah-langkah sebagai berikut:

a) Upah Minimum (X1)

Langkah-langkah pengujian:

$\mathrm{H}_{0}: \beta 1=0$ (tidak ada pengaruh)

$\mathrm{Ha}_{\mathrm{a}}: \beta 1 \neq 0$ (ada pengaruh)

$\alpha=0,05$ dengan $\mathrm{df} 2=6$

$\mathrm{t}$ Hitung $=-3,916$

Level of significant $=0,05 / 2=0,025$

berarti $\mathrm{t}$ Tabel $=2,446$

Daerah pengujian terhadap tingkat kemiskinan (Y). Berdasarkan perhitungan diperoleh t-hitung sebesar - 3,916 $<$ t-tabel sebesar 2,446 maka $\mathrm{H} 0$ ditolak dan $\mathrm{Ha}$ diterima.. Yang artinya bahwa secara parsial variabel Upah Minimum (X1) berpengaruh terhadap Tingkat Kemiskinan. Hal ini didukung juga dengan nilai signifikan dari Upah Minimum (X1) sebesar 0,006 yang lebih kecil dari 0,05.

b) Tingkat Pengangguran (X2)

Langkah-langkah pengujian:

$\mathrm{H} 0: \beta 2=0$ (tidak ada pengaruh)

$\mathrm{Ha}: \beta 2 \neq 0$ (ada pengaruh)

$\alpha=0,05$ dengan $\mathrm{df} 2=6$

$\mathrm{t}$ Hitung $=0,030$

Level of significant $=0,05 / 2=0,025$ berarti t Tabel $=2,446$

Daerah pengujian terhadap tingkat kemiskinan (Y). Berdasarkan perhitungan diperoleh t-hitung sebesar $0,030<\mathrm{t}$ - tabel sebesar 2,446 maka $\mathrm{H} 0$ diterima dan $\mathrm{Ha}_{\mathrm{a}}$ ditolak. Yang artinya bahwa secara parsial variabel Tingkat Pengangguran (X2) tidak berpengaruh terhadap tingkat kemiskinan. Hal ini didukung juga dengan nilai signifikan dari Tingkat Inflasi (X2) sebesar 0,977 yang lebih besar dari 0,05.

c) Jumlah Penduduk (X3)

Langkah-langkah pengujian:

$\mathrm{H} 0: \beta 1=0$ (tidak ada pengaruh)

$\mathrm{H}_{\mathrm{a}}: \beta 1 \neq 0$ (ada pengaruh)

$\alpha=0,05$ dengan $\mathrm{df} 2=6$

$\mathrm{t}$ Hitung $=-4,688$

Level of significant $=0,05 / 2=0,025$

berarti t Tabel $=2,446$

Daerah pengujian terhadap tingkat kemiskinan (Y). Berdasarkan perhitungan diperoleh t-hitung sebesar $\mathbf{- 4 , 6 8 8}<\mathrm{t}$-tabel sebesar 2,446 maka $\mathrm{H} 0$ ditolak dan $\mathrm{Ha}_{\mathrm{a}}$ diterima. Yang artinya bahwa secara parsial variabel Jumlah Penduduk (X3) berpengaruh terhadap Tingkat Kemiskinan. Hal ini didukung juga dengan nilai signifikan dari Upah Minimum (X1) sebesar 0,002 yang lebih kecil dari 0,05.

\section{Penjelasan}

Upah Minimum, Tingkat Pengangguran, Jumlah Penduduk mampu menjelaskan tingkat kemiskinan sebesar $94,6 \%$, sedangkan sisanya $5,4 \%$ adalah dijelaskan oleh variabel - variabel diluar variabel pada model penelitian. Secara parsial, Upah Minimum dan Jumlah Penduduk berpengaruh negatif terhadap tingkat kemiskinan Sedangkan Tingkat Pengangguran Tidak berpengaruh dan signifikan terhadap tingkat Kemiskian.

\section{Pengaruh Upah Minimum Terhadap Kemiskinan}

Hasil dari penelitian ini ialah menunjukkan setiap upah minimum naik seratus ribu, maka tingkat kemiskinan akan turun sebesar 0,00008\% apabila tingkat pengangguran dan Jumlah Penduduk konstan. Hasil penelitian ini sejalan dengan penelitian yang dilakukan oleh (Soejoto\&Karisma,2010. pp.15) yang menjelaskan bahwa upah minimum merupakan masalah pembangunan di tingkat kemiskinan dalam keterbatasan ketidakmampuan, dan kekurangan. Dalam pasar tenaga kerja sangat penting untuk menetapkan besarnya upah yang harus dibayarkan 
perusahaan pada pekerjanya sehingga dapat mengurangi keesenjangan antara upah terendah dan tertinggi di perusahaan.

\section{Pengaruh Tingkat Pengangguran Terbuka Terhadap Kemiskinan}

Hasil dari penelitian ini ialah menunjukkan setiap tingkat pengangguran terbuka naik satu persen, maka tingkat kemiskinan akan naik sebesar 0,014\% apabila upah minimum dan jumlah penduduk. Hasil penelitian ini sejalan dengan penelitian yang dilakukan oleh (Rifqi Muslim,2014. pp.15) yang menjelaskan pembangunan ekonomi ditujukan guna meningkatkan kesejahteraan masyarakat di sisi ekonomi maupun sisi social. salah satu tujuan dari pembangunan ekonomi itu sendiri yaitu menciptakan kesempatan dan lapangan kerja semaksimal mungkin supaya angkatan kerja yang berada di dalam suatu Negara tersebut dapat terserap dalam proses kegiatan ekonomi di Negara tersebut serta terciptanya pertumbuhan serta peningkatan sumber daya manusia (SDM). Semakin banyak pengangguran maka PDRB yang dihasilkan akan menurun, dengan demikian pendapatan perkapita yang rendah mengakibatkan tingkat kesejahteraan menurun dan meningkatnya kemiskinan.

\section{Pengaruh Jumlah Penduduk Terhadap Kemiskinan}

Hasil dari penelitian ini ialah menunjukkan setiap jumlah pemduduk naik seratus ribu, maka tingkat kemiskinan akan turun sebesar 0,0019\% apabila upah minimum dan tingkat pengangguran konstan. Hasil penelitian ini sejalan dengan penelitian (Hermanto\&Winarti,2006. pp.14) yang menjelaskan agar mengetahui dan menganalisis pengaruh serta dampak dari pertumbuhan ekonomi terhadap jumlah penduduk miskin Indonesia, hal ini dilakukan karena jumlah penduduk miskin akibat krisis belum berhasil dikurangi bahkan cenderung meningkat. Pertumbuhan penduduk berkaitan dengan kemiskinan dan kesejahteraan masyarakat dengan tingkat kelahiran yang tinggi maka akan menyebabkan beban biaya dalam suatu keluarga juga akan bertambah sehingga hal ini menyebabkan beban biaya dalam suatu keluarga juga akan bertambah sehingga hal ini menyebabkan beban ketergantungan ekonomis.

\section{DAFTAR PUSTAKA}

Arsyad, Lincolin. (2004). Ekonomi Pembangunan, Sekolah Tinggi Ilmu Ekonomi, Yogyakarta.

Alvonita, dkk. (2014). Pengaruh Tingkat Pengangguran dan Upah Minimum Provinsi

\section{KESIMPULAN DAN SARAN}

Berdasarkan hasil penelitan, ditarik kesimpulan sebagai berikut: (1) Upah minimum mempunyai pengaaruh yang negatife dan signifikan terhadap kemiskinan Jawa Tengah. Hal ini dijelaskan bahwa adanya ketentuaan nilai upah minimumini jumIahnya harus diatas kebutuhan hidup layak masyarakat yang artinya bahwa adanya kenaikan upah tIdak akan berarti jika angka kebutuhan hidup layak masih berkisar di atas jumlah upah minimum. (2) Tingkat pengangguran terbuka mempunyai pengaruh yang positif dan signifikan terhadap kemiskinan di Jawa Tengah. Hal ini dijelaskan bahwa perluasan kesempatan kerja untuk menciptakan kondisi dan lingkungan ekonomi, politik, sosial yang memungkInkan masyarakat miskin dapat memperoleh kesempatan dalam pemenuhan hak-hak dasar dan peningkatan taraf hidup secara berkelanjutan. (3) Jumlah penduduk mempunyai pengaruh yang positif dan signifikan terhadap kemiskinan di Jawa Tengah. Pertumbuhan jumlah penduduk yang tinggi tanpa diimbangi dengan perbaikan kualitas penduduk serta penIngkatan sumber daya pangan akan menjadikan kemiskinan semakin meningkat, serta tidak terkendali dan menghambat proses pembangunan ekonomi. (4) Upah minimum, tingkat pengangguran terbuka, dan jumlah penduduk secara bersama-sama berpengaruh terhadap kemiskinan di Provinsi Jawa Tengah.

Berdasarkan hasil penelitian yang telah dilakukan, maka saran yang dapat dilihat sebagai berikut: (1) Pemerintah Provinsi Jawa Tengah lebih menggerakkan sektor informal, karena pengangguran dalam penelitian ini menggunakan data pengangguran terbuka yang mana didalamnya terdapat golongan masyarakat yang sedang mencari pekerjaan, menyiapkan usaha atau sudah mendaapatkan pekerjaan namun belum mulai bekerja yang masuk dalam golongan pengangguran. (2) Penetapan pada kebijakan upah minimum harus tetap dilakukan dan tingkat upahnya dinaikkan sesuai KHL (Kebutuhan Hidup Layak) untuk melindungi pekerja dari kemiskinan. (3) Pemerintah Kabupaten/Kota di Jawa Tengah harus Iebih memperhatikan laju pertumbuhan penduduk di desa, karena angka kelahiran di desa Iebih besar daripada daripada di kota, sehingga focus utama program Keluarga Berencana (KB) lebih baik dilakukan di desa.

Terhadap tingkat Kemiskinan di Provinsi Riau, JOM FEKON, Vol.1 No.2, Oktober 2014. 
Basri Yuswar Zainul dan Subri Mulyadi. (2003). Keuangan Negara dan Analisis Kebijakan Pinjaman Luar Negeri, PT Raja Grafindo Persada, Jakarta.

Badan Perencanaan Pembangunan Daerah (Bappeda) Provinsi Jawa Tengah. (2007). Semarang.

Badan Pusat Statistik Jakarta Pusat. (2010). Statistik Indonesia Tahun 2010. Jakarta Pusat: Badan Pusat Statistik.

Bintang, A.B \& Woyanti, N. (2018). Pengaruh PDRB, Pendidikan, Kesehatan, dan Pengangguran Terhadap Tingkat Kemiskinan Di Jawa Tengah (2011-2015). Jurnal Media Ekonomi dan Manajemen, Vol 33, No.1.

Feriyanto, Nur. (2014). Ekonomi Sumber Daya Manusia Dalam Perspektif Indonesia, UPP STIM YKPN, Yogyakarta.

Gujarati, Damodar N dan Dawn C. Porter. (2010). Dasar-Dasar Ekonometrika. Buku 1. Edisi 5. Jakarta: Salemba Empat.

Ghozali. (2014). Aplikasi Analisis Multivariate dengan Program SPSS. Badan Penerbit UNDIP, Semarang.

Hermanto, S., \& Dwi, W. (2008). Dampak Pertumbuhan Ekonomi Terhadap Penurunan Jumlah Penduduk Miskin, Diakses 8 Desember 2017, dari http://pse.litbang.deptan.go.id/ind/pdffiles/P ROS 2008_MAK3.pdf.

Indriantoro, Nur dan Bambang Supomo. (2011). Metodologi Penelitian Bisnis Untuk Akuntansi Dan Manajemen, Edisi Pertama. BPFE, Yogyakarta

Kuncoro, Mudrajad. (2004). Ekonomi Pembangunan: Teori Masalah dan Kebijakan, UPP AMP YKPN, YOGYAKARTA.

Mankiw Gregory. (2006). Pengantar Ekonomi Makro, Edisi Ketiga. Salemba Empat Jakarta.

Nasir, M., Muh, Saichudin dan Maulizar. (2008). Analisis Faktor-faktor Yang Mempengaruhi Kemiskinan Rumah Tangga di Kabupaten Purworejo. Jurnal Eksekutif, Vol. 5, No. 4.

Pratama, Y.C. (2014). Analisis Faktor-Faktor Yang Mempengaruhi Kemiskinan di Indonesia. Jurnal Bisnis dan Manajemen, Vol.4, No. 2.

Paramita, S., Anwar, D., \& Darussamin. (2016). Analisis PDRB, Tingkat Pendidikan dan Tingkat Pengangguran Terhadap Tingkat Kemiskinan Di Provinsi Sumatera Selatan Periode 2004-2013 I-Economic Volume 2, No.1, 86-101.

Rusdati. \& Lesta, K.S. (2013). Faktor-Faktor Yang Mempengaruhi Tingkat Kemiskinan di Provinsi Jawa Tengah. Jurnal Economia.
Sumarsono, Sonny. (2003). Ekonomi Manajemen Suber Daya Manusia dan Ketenagakerjaan, Graha Ilmu, Yogyakarta.

Suparlan, Parsudi. (2004). Masyarakat dan Kebudayaan Perkotaan. Jakarta: Yayasan Pengembangan Kajian Ilmu Kepolisian.

Sukirno, Sadono. (2006). Teori Pengantar Makro Ekonomi. Raja Grafindo Persada Jakarta.

Suliswanto, M. (2010). Pengaruh Produk Domestik Regional Bruto (PDRB) dan Indeks Pembangunan Manusia (IPM) Terhadap Angka Kemiskinan di Indonesia. Jurnal Ekonomi Pembangunan, Vol.8, No.2.

Suliyanto. (2011). Ekonometrika Terapan: Teori Dan Aplikasi Dengan SPSS. Edisi 1. Yogyakarta: ANDI Yogyakarta.

Saputra, W.A. (2011). Analisis Pengaruh Jumlah Penduduk, PDRB, IPM, Pengangguran Terhadap Tingkat Keemiskinan Di Kabupaten/Kota Provinsi Jawa Tengah. Universitas Diponegoro.

Soejoto, A., \& Karisma, M. (2013). Pertumbuhan Ekonomi dan Pengangguran Terhadap Penurunan Jumlah Penduduk Miskin. Jurnal Ekonomi Pembangunan, Hal 1-5.

Subri, Mulyadi. (2013). Ekonomi Sumber Daya Manusia, Jakarta: PT. Raja Grafindo Persada.

Sugiyono. (2014). Metode Penelitian Kuantitatif Kualitatif dan R\&D. Bandung: Alfabeta.

Widarjono, Agus. (2009). Ekonometrika Pengantar dan Aplikasinya Edisi ketiga, Ekonisia, Jakarta.

Wongdesmiati. (2009). Pertumbuhan Ekonomi dan Pengentasan Kemiskinan Di Indonesia, Diakses 6 Desember 2017, dari http://wondesmiati.files.wordpress.com/2009 /10/pertumbuhan-ekonomi-dan-pengentasankemiskinan-di-indonesia-_analisisekonometri_.pdf. 